\title{
EFEKTIVITAS KONSENTRASI SARI LIDAH BUAYA DAN SARI LEMON DALAM MEREDUKSI TAHU YANG BERFORMALIN
}

\author{
Connie Daniela ${ }^{1}$ \\ Herla R usmarilin ${ }^{2}$ \\ Hotnida Sinaga ${ }^{3}$ \\ 1,2,3) Pascasarjana Program Studi Ilmu Pangan, Fakultas Pertanian, Universitas Sumatera Utara \\ conniedaniela83@gmail.com, herla_surabaya@yahoo.com, hotnida.sinaga@uq.net.au
}

\begin{abstract}
Tofu is so damaged that sellers know often add preservatives like formalin. Formalin toxic compounds are carcinogenic. Aloe vera and lemon juice are able to minimize the presence of formalin. This study aims to determine the effect of concentration and duration of immersion of aloe vera and lemon juices in reducing formalin. Tofu used has been soaked formalin $1 \%$ then added aloe vera and lemon juice. This experiment was conducted experimentally using Factorial Complete Random Design consisting of two factors, concentration of aloe vera with lemon juices 100\%:0\%, 80\%:20\%, 60\%:40\%, 40\%:60\%, 20\%:80 \%, 0\%:100\% and immersion time 30, 60, 90 (minutes) and Nonfactorial Completely Randomized Design, treatment for storage duration 0, 3, 6, 9 (days). The parameters are formalin ( $\mathrm{mg} / \mathrm{kg})$, protein (\%), and total microbial (log CFU/ml) levels. The samples were tested on the long treatment of storage, the largest decrease in formaldehyde. The results showed that the ratio of aloe vera and lemon juices and soaking time had a significant effect on formalin content (\%), total microbial (log CFU/ml), and protein content (\%). Levels of formaldehyde know that has been soaked formalin $1 \%$ amounting to $84,214(\mathrm{mg} / \mathrm{kg})$, the protein content of $3.8 \%$, total microbial (log $\mathrm{CFU} / \mathrm{ml}$ ). The best treatment in the decrease of formalin content is $100 \%$ aloe vera juices with immersion 90 minutes, the remaining formalin is 28,678 ( $\mathrm{mg} / \mathrm{kg}$ ) or decreases the formalin content in tofu by $65,94 \%$. Aloe vera juice contains saponin compounds that act as surfactants that are capable of removing formaldehyde in tofu.
\end{abstract}

Kata kunci: a loe vera, formalin, lemon, tahu.

Tahu adalah salah satu produk kedelai yang banyak diminati oleh negara-negara di Asia khususnya Indonesia. Tahu mengandung sekitar $50 \%$ protein dan sumber kalsium yang baik. Konsumsi produk kedelai secara teratur mengurangi risiko penyakit kronis seperti kanker, penyakit jantung, dan stroke (Jooyandeh, 2011). Kelemahan tahu, yaitu tahu diklasifikasikan sebagai makanan yang mudah rusak, yang dikaitkan dengan umur simpannya yang pendek. Oleh sebab itu, untuk menghindari kerugian besar, produsen sering menambahkan bahan pengawet seperti formalin. Formalin adalah salah satu bahan pengawet yang dilarang secara resmi untuk digunakan sebagai bahan pengawet makanan, sesuai peraturan Menteri Kesehatan Republik Indonesia No. 033 tahun 2012 tentang Bahan Tambahan Pangan (BPOM, 2017)

Formalin adalah senyawa reaktif yang dapat mengikat senyawa dalam bahan makanan, seperti protein, lemak, dan karbohidrat. Mekanisme formalin sebagai pengawet adalah ketika formaldehida bereaksi dengan protein untuk 
membentuk sekuens antara protein yang berdekatan. Sebagai hasil dari reaksi ini, protein mengeras dan tidak dapat larut (Shita, 2016). Protein yang tidak bisa dicerna makanan akan menjadi bahan asing (antigen) bagi tubuh, sehingga menimbulkan respon imun (Wikanta, 2011). Pemberian formalin pada udang putih (Wikanta, 2011) telah terbukti mempengaruhi nilai gizi protein diet (asam amino dan PER) dan merusak organ hewan percobaan.

Formalin juga merupakan sumber reaktif oksigen (SOR) dan radikal bebas eksogen. Vitamin $\mathrm{E}$ dan vitamin $\mathrm{C}$ memiliki potensi dalam hal menangkap senyawa oksigen reaktif. Berdasarkan laporan kejadian luar biasa yang diterima POM pada 2016, 6.136 orang terpapar makanan yang diduga menyebabkan keracunan, 3.413 orang sakit, dan 8 kematian (BPOM, 2017).

Dengan demikian, makanan formalin merupakan ancaman bagi kesehatan dan keselamatan kehidupan masyarakat, baik dalam jangka pendek maupun jangka panjang. Oleh karena itu, harus ada upaya yang harus dilakukan untuk memastikan bahwa makanan yang dikonsumsi bebas dari formalin, salah satunya menggunakan bahan alami seperti lidah buaya dan lemon yang sangat mudah ditemukan di Indonesia.

Senyawa saponin yang terkandung dalam lidah buaya berpotensi menurunkan formalin dengan cara perendaman. Cara saponin bekerja pada gel lidah buaya dapat menurunkan tingkat formalin yang dikenal sebagai reaksi saponifikasi (proses pembentukan sabun) dimana sabun tersebut termasuk dalam kelompok surfaktan
(Gusviputri, 2013). Berdasarkan penelitian sebelumnya Jannah, et al., (2014) lengkuas (Alpinia galanga) $20 \%$ dengan perendaman 60 menit menurunkan kadar formalin sebesar $64 \%$ pada udang putih.

Asam sitrat digunakan sebagai bahan pembersih yang ramah lingkungan. Aktivitas antioksidan dari sampel lemon (Citrus limon L) dilaporkan oleh Ali, et al., 2010. Kehadiran antioksidan yang ditemukan dalam jeruk nipis menjadi salah satu faktor pendukung penurunan kandungan formalin dalam tahu formalin.

Berdasarkan beberapa penelitian sebelumnya yang menunjukkan keefektifan saponin untuk mengurangi senyawa formalin maka penelitian ini bertujuan untuk melihat pengaruh perbandingan sari lidah buaya dan sari lemon dalam mereduksi formalin serta pengaruhnya terhadap masa simpan tahu.

\section{METODE}

\section{Alat dan Bahan}

Peralatan yang digunakan dalam penelitian ini adalah labu analitik kjedahl $100 \mathrm{ml}$, peralatan distilasi (Gerhard), buret, erlenmeyer $100 \mathrm{ml}$, volumetrik labu $100 \mathrm{ml}$, volume pipet $10 \mathrm{ml}$, cawan petridish, autoclave (GEA), dan HPLC (shimadzu). Bahan yang digunakan dalam penelitian ini adalah kacang kedelai diperoleh dari pasar lokal. Lidah buaya jenis Barbadensis Miller. Buah lemon timur tengah yang diperoleh dari perkebunan lemon di Jl. Bunga Sedap Malam Sempakata, Medan Selayang. Bahan kimia yang digunakan dalam penelitian ini adalah $\mathrm{H}_{2} \mathrm{SO} 4$ (merck), $\mathrm{NaOH} 50 \%$ (merck), asam borat (merck), 
indikator metil merah (merck), HCL (merck), aquadest, formaldehida $37 \%$ (merck), dinitrofenilhidrazin 0,1 $\%$, diklorometana (merck), metanol (smart lab), plat count agar (oxoid).

\section{Metode Eksperimen \\ Desain Eksperimen}

Penelitian ini menggunakan

Rancangan Acak Lengkap (RAL) faktorial dan Rancangan Acak Lengkap (RAL) nonfaktorial. RAL faktorial terdiri atas 2 faktor. Faktor pertama (perbandingan sari lidah buaya dan sari lemon) terbagi menjadi 6 taraf, yaitu 100:0, 80:20, 60:40, 40:60, 20:80, dan 0:100 (\%). Faktor kedua (lama perendaman) terbagi atas 3 taraf, yaitu 30, 60, dan 90 (menit). RAL nonfaktorial perlakuan terhadap lama penyimpanan, yaitu $0,3,6$, dan 9 (hari). Dilakukan 3 kali ulangan untuk setiap analisa.

\section{Prosedur Kerja}

Penelitian ini menggunakan dua tahapan. Tahap pertama dimulai dengan pembuatan simulasi tahu, pembuatan larutan formalin $1 \%$, pembuatan sari lidah buaya dan sari lemon.

\section{Persiapan Pembuatan Tahu}

Disortasi kedelai dicuci, direndam dalam air bersih selama 12 jam. Kacang kedelai dihancurkan dengan menggunakan blender, ditambahkan air hangat dengan rasio kedelai dan air adalah 1:2. Disaring, filtrat dipanaskan, diaduk, ditambahkan asam asetat sampai terbentuk gumpalan. Tahu siap untuk dipadatkan dan untuk digunakan.

Pembuatan Sari Lidah Buaya dan Sari Lemon

Pembuatan sari lidah buaya.

Lidah buaya dicuci, dilepaskan lapisan kuning tepat di bawah kulit dan dibuang. Diblansing, dilumatkan dengan blender, disaring. Pembuatan jus lemon, Potong lemon menjadi dua bagian, diperas, disaring sehingga menghasilkan sari yang jernih. Masing-masing sari disesuaikan dengan persentase yang digunakan dalam penelitian, yaitu 100, 80, 60, 40, 20, dan $0(\%)$.

\section{Perendaman Tahu ke dalam Sari Lidah Buaya dan Sari Lemon \\ Tahu formalin direndam ke} dalam campuran jus lidah buaya dan jus lemon dengan perbandingan masing masing 100\%:0\% (A1) 80\%:20\% (A2), 60\%:40\% (A3) 40\%:60\% (A4), 20\%:80\% (A5) 0\%:100\% (A6) yang kemudian direndam selama 30 (L1), 60 (L2), dan 90 (L3) (menit) setiap perlakuan dianalisis untuk kandungan formalin, kandungan protein, dan total mikroba.

Perlakuan terbaik diperoleh dari penurunan kandungan formalin terbesar yang kemudian dilanjutkan untuk perlakuan penyimpanan. Tahu akan disimpan dalam penyimpanan dingin untuk lama penyimpanan (M) untuk hari 0 (M1), 3 (M2), 6 (M3), dan 9 (M4) yang kemudian akan dianalisis terhadap total mikroba.

\section{Analisis HPLC untuk Penentuan Formaldehida}

Protokol yang dimodifikasi untuk mendeteksi formaldehid dalam tahu dengan instrumen HPLC (Model SPD-M20 A) berdasarkan metode yang dijelaskan oleh Ali et al., (2007)

Preparasi Sampel

Tahu dipotong berbentuk dadu dan dihaluskan dengan menggunakan mortal dan alu. Sampel ditimbang sebanyak $\pm 5 \mathrm{~g}$ dan ditambahkan $50 \mathrm{~mL}$ aqua 
demineralisasi (DM), dipanaskan pada suhu $96^{\circ} \mathrm{C}$ selama 30 menit. Sampel disaring menggunakan kertas saring untuk mendapatkan filtrat yang mengandung formaldehid, kemudian filtratnya disentrifugasi pada 3000 rpm selama 10 menit dan diperoleh supernatan, dimasukkan ke dalam botol dan dilakukan degassing menggunakan alat Branson 5200 Ultrasonic Cleaner.

\section{Derivatisasi Formalde hida}

Sampel filtrat dan larutan standar (20 ppm, $60 \mathrm{ppm}, 80 \mathrm{ppm}$, dan $100 \mathrm{pp}$ ) diambil masing-masing $1 \mathrm{~mL}$. Sebanyak 0,5 mL larutan DNPH 0,1\% ditambahkan, kemudian diekstraksi menggunakan diklorometana. Setelah fase diklorometana diguncang, diambil dan fasa air dikeluarkan. Diklorometana diuapkan dan residu evaporasi dilarutkan dengan $1 \mathrm{~mL}$ metanol. Larutan kemudian disaring menggunakan filter membran 0,45 $\mu \mathrm{m}$ sebelum injeksi. Untuk setiap sampel dua ulangan dianalisis. Hasil dinyatakan sebagai $\mathrm{mg} / \mathrm{kg}$.

\section{Kondisi Analitik HPLC}

HPLC yang digunakan adalah

HPLC shimadzu tipe LC-20AT/ SPD-20A, yang terdiri dari tipe pompa LC-20AT, tipe kolom VPODS $(250 \times 4,6 \mathrm{~mm}), \mathrm{UV}-\mathrm{V}$ is mendeteksi SPD-20A. Volume sampel diatur pada $20 \mu 1$ dan panjang gelombang detektor penyerapan diatur pada $355 \mathrm{~nm}$ dan suhu oven pada suhu $30^{\circ} \mathrm{C}$. Pemisahan dicapai dengan menggunakan elusi isokratik dengan campuran air / metanol $(35: 65 \mathrm{v} / \mathrm{v})$. Total run time adalah 10 menit. Daerah puncak digunakan untuk perhitungan formaldehida kuantitatif.

\section{Penentuan Kandungan Protein (AOAC, 1970)}

Sampel 0,5 g dimasukkan ke dalam labu kjedahl, ditambahkan 1,5 g selenium dan $15 \mathrm{ml} \mathrm{H}_{2} \mathrm{SO} 4$, dilarutkan dalam ruang asam ke larutan yang jelas, diikuti pemanasan selama 1 jam, didinginkan. Kemudian encerkan dengan aquadest dalam labu ukur, suling dengan penambahan $20 \mathrm{ml} \mathrm{NaOH} 50 \%$. Produk distilasi diakomodasi dengan $10 \mathrm{ml}$ asam borat dan 3 tetes indikator metil merah. Penyulingan dilakukan sampai tempat penampungan mencapai $100 \mathrm{ml}$. Kemudian hasil distilasi dititrasi dengan 0,02 $\mathrm{N} \mathrm{HCl}$ sampai pink terbentuk.

Penentuan Total Mikroba (Fardiaz, 1989).

Menguji jumlah mikroba dengan menggunakan metode pelat yang dihitung atau "pour plate". Bahan ditimbang $5 \mathrm{~g}$ dan dimasukkan ke dalam labu erlenmeyer yang mengandung $45 \mathrm{ml}$ garam fisiologis steril (pengenceran $10^{-1}$ ), seri pengenceran dilakukan pada 10 sekurang-kurangnya 5 pengenceran.

Dipipet $1 \mathrm{ml}$ dari 3 pengenceran terakhir kemudian dimasukkan ke dalam petridish steril lalu dituangkan media PCA kira-kira $15 \mathrm{ml}$. Dibiarkan mengeras dan dibungkus dengan bungkus plastik lalu diinkubasi selama 48 jam pada suhu $37^{\circ} \mathrm{C}$. Setelah 48 ja dihitung jumlah koloni mikroba yang terkandung di dalam cawan dengan ketentuan jumlah koloni dihitung antara 30-300. 


\section{HASIL}

\section{Pengaruh Konsentrasi Sari Lidah Buaya dan Sari Lemon Terhadap Parameter Mutu Tahu}

Hasil penelitian menunjukkan bahwa perbandingan sari lidah buaya dan sari lemon memberikan pengaruh terhadap kadar formalin (\%), total mikroba $(\log \mathrm{CFU} / \mathrm{ml})$, dan kadar protein. Pengaruh perbandingan sari lidah buaya dan sari lemon terhadap parameter mutu tahu yang diamati dapat dilihat pada Tabel 1, sedangkan pengaruh lama perendaman terhadap parameter mutu tahu dapat dilihat pada Tabel 2. Tabel 3 menunjukkan pengaruh lama penyimpanan terhadap total mikroba tahu.

Tabel 1 menunjukkan bahwa kadar formalin tertinggi diperoleh pada perlakuan A6 (0\%:100\%) sebesar 65,161 (mg/kg) dapat menurunkan kadar formalin sebesar
$22,63 \%$ dan terendah pada perlakuan A1 (100\%:0\%) sebesar 36,163 $(\mathrm{mg} / \mathrm{kg})$. Total mikroba yang tertinggi diperoleh pada perlakuan sari lidah buaya $100 \%$, yaitu 5,083 $(\log \mathrm{CFU} / \mathrm{ml}) \quad$ sedangkan yang terendah pada perlakuan sari lemon $100 \%$, yaitu 2,861 Kadar protein sari lemon $100 \%$ menghasilkan kadar protein terendah dan kadar protein tertinggi pada perlakuan sari lidah buaya $100 \%$.

Tabel 2 menunjukkan bahwa semakin lama perendaman maka kadar formalinnya semakin menurun. Lama perendaman 90 menit dapat menurunkan sebesar 50,42\% dengan sisa formalin sebesar 41,752 $(\mathrm{mg} / \mathrm{kg})$. Total mikroba yang tertinggi diperoleh pada perlakuan L3 (90 menit), yaitu 4,640 $(\log \mathrm{CFU} / \mathrm{ml})$ sedangkan yang terendah diperoleh pada perlakuan L1 (130 menit), yaitu 3,978 $(\log \mathrm{CFU} / \mathrm{ml})$.

Tabel 1. Pengaruh Perbandingan Sari Lidah Buaya dan Sari Lemon Terhadap Parameter Mutu Tahu.

\begin{tabular}{|c|c|c|c|}
\hline \multirow{2}{*}{ Perlakuan } & \multicolumn{3}{|c|}{ Parameter } \\
\cline { 2 - 4 } & $\begin{array}{c}\text { Kadar } \\
\text { formalin }(\%)\end{array}$ & $\begin{array}{c}\text { Total mikroba (log } \\
\text { CFU/ml) }\end{array}$ & Kadar protein (\%) \\
\hline A1 & $36,163^{\mathrm{g}}$ & $5,083^{\mathrm{b}}$ & $5,541^{\mathrm{b}}$ \\
\hline A2 & $41,093^{\mathrm{f}}$ & $4,968^{\mathrm{b}}$ & $5,395^{\mathrm{c}}$ \\
\hline A3 & $46,499^{\mathrm{e}}$ & $4,858^{\mathrm{c}}$ & $5,232^{\mathrm{d}}$ \\
\hline A4 & $53,312^{\mathrm{d}}$ & $4,301^{\mathrm{d}}$ & $4,856^{\mathrm{e}}$ \\
\hline A5 & $57,976^{\mathrm{c}}$ & $4,170^{\mathrm{d}}$ & $4,530^{\mathrm{f}}$ \\
\hline A6 & $65,161^{\mathrm{b}}$ & $2,861^{\mathrm{e}}$ & $4,337^{\mathrm{g}}$ \\
\hline Tahu kontrol & $0,000^{\mathrm{h}}$ & $5,552^{\mathrm{a}}$ & $6,331^{\mathrm{a}}$ \\
\hline Tahu formalin & $84,214^{\mathrm{a}}$ & $0,000^{\mathrm{f}}$ & $3,800^{\mathrm{h}}$ \\
\hline
\end{tabular}


Tabe1 2. Pengaruh Lama Perendaman terhadap Parameter Mutu Tahu

\begin{tabular}{|c|c|c|c|}
\hline \multirow{2}{*}{ Perlakuan } & \multicolumn{3}{|c|}{ Parameter } \\
\cline { 2 - 4 } & $\begin{array}{c}\text { Kadar formalin } \\
(\%)\end{array}$ & $\begin{array}{c}\text { Total mikroba (log } \\
\text { CFU/ml) }\end{array}$ & Kadar protein (\%) \\
\hline L1 & $58,457^{\mathrm{b}}$ & $3,978^{\mathrm{c}}$ & $4,817^{\mathrm{d}}$ \\
\hline L2 & $49,892^{\mathrm{c}}$ & $4,502^{\mathrm{b}}$ & $4,968^{\mathrm{c}}$ \\
\hline L3 & $41,752^{\mathrm{d}}$ & $4,640^{\mathrm{b}}$ & $5,161^{\mathrm{b}}$ \\
\hline Tahu kontrol & $0,000^{\mathrm{e}}$ & $5,552^{\mathrm{a}}$ & $6,331^{\mathrm{a}}$ \\
\hline Tahu formalin & $84,214^{\mathrm{a}}$ & $0,000^{\mathrm{d}}$ & $3,800^{\mathrm{f}}$ \\
\hline
\end{tabular}

Tabe13. Pengaruh Lama Penyimpanan terhadap Total Mikroba Tahu

\begin{tabular}{|c|c|c|c|}
\hline Perlakuan & $\begin{array}{l}\text { Penyimpanan } \\
\text { 3 hari } \\
6 \text { hari }\end{array}$ & $\begin{array}{l}\text { Penyimpanan } \\
\text { Phari }\end{array}$ \\
\hline Tahu kontrol & $6,4206^{\mathrm{a}}$ & $6,9135^{\mathrm{a}}$ & $7,1703^{\mathrm{a}}$ \\
\hline $\begin{array}{c}\text { A1L3 } \\
\text { (sari lidah buaya 100\%, } \\
\text { lama perendaman 90 menit) }\end{array}$ & $5,2987^{\mathrm{b}}$ & $5,9215^{\mathrm{b}}$ & $6,2208^{\mathrm{b}}$ \\
\hline Tahu formalin & $3,8819^{\mathrm{c}}$ & $4,6910^{\mathrm{c}}$ & $5,7864^{\mathrm{c}}$ \\
\hline
\end{tabular}

PEMBAHASAN

Kadar Formalin

Perlakuan A1 (100\%:0\%), yaitu sari lidah buaya $100 \%$ adalah perlakuan terbaik karena menurunkan kadar formalin terbesar. Hal tersebut menunjukkan bahwa persentase sari lidah buaya yang tinggi memiliki kemampuan mereduksi kandungan formalin yang lebih baik jika dibandingkan dengan sari lemon. saponin tersebut dikarenakan adanya kandungan saponin yang tinggi di dalam lidah buaya.

Wirawan, et al., (2017) menemukan bahwa saponin yang terkandung dalam daun singkong mampu mereduksi kandungan formalin pada udang putih. Rosida, (2002), kandungan saponin pada lidah buaya sebesar $500 \mu \mathrm{g} / \mathrm{ml}$.

Saponin yang terkandung pada lidah buaya mereduksi formalin dalam tahu melalui reaksi saponifikasi. Zat surfaktan dalam saponin bersifat ampifatik yaitu memiliki gugus hidrofobik (non polar) dan hidrofilik (polar) sehingga dapat membentuk emulsi air dan formalin, sehingga saponin berperan sebagai emulgator. Senyawa saponin teradsorbsi ke daerah antar fase dan mengikat partikel formaldehida sehingga diperoleh kestabilan emulsi dari gugus polar. Setelah formalin terikat oleh senyawa saponin, maka saponin akan larut dan membentuk misel (micelles). Bagian misel berinteraksi dengan air dan formalin sehingga formalin dapat larut bersama air.

\section{Total Mikroba}

Tabel 1 menunjukkan bahwa pada tahu berformalin, jumlah mikroba adalah 0,00 $\log \mathrm{CFU} / \mathrm{ml}$ atau dapat dikatakan bahwa tahu berformalin tidak mengandung mikroba. Hal tersebut disebabkan karena formalin 
mampu melindungi bahan makanan dari kerusakan yang disebabkan oleh mikroba. Formalin mampu menghambat pertumbuhan mikroba aerobik pada konsentrasi yang sangat.

Tabel 2 menunjukkan tahu yang diberi perlakuan perendaman dengan sari lidah buaya dan sari lemon, diketahui bahwa mikroba paling sedikit dijumpai pada perlakuan A6 dan lama perendaman 30 menit. Hal ini dikarenakan kandungan formalin dalam sampel masih tinggi sehingga formalin masih mampu untuk menghambat pertumbuhan mikroba meskipun mikroba dapat tumbuh dalam jumlah yang rendah. Penelitian Ramesh, et al., (2017) menunjukkan bahwa pada larutan formalin $10 \%$ dapat ditumbuhi oleh mikroba CoNS dan E.coli. Bakteri anaerobik umumnya kurang rentan terhadap formalin karena dinding selnya yang kompleks.

Jumlah mikroba tertinggi diperoleh pada perlakuan A1 (100\%:0\%) dan lama perendaman L3 (90 menit). Tingginya jumlah mikroba tersebut dikarenakan banyaknya jumlah formalin yang terurai oleh senyawa yang terkandung dalam lidah buaya sehingga ikatan silang antara protein dan fomaldehid terlepas. Pelepasan ikatan silang tersebut menyebabkan tingginya kandungan protein yang dapat digunakan oleh mikroba sebagai substrat untuk pertumbuhannya. Menurut Hershey dan Chase (2017) protein dan asam nukleat merupakan media pertumbuhan yang sangat baik bagi mikroorganisme.

\section{Kadar Protein}

Tabel 1 menunjukkan pada perlakuan kontrol, tahu memiliki kandungan protein sebesar $6,331 \%$ dan ketika diberi formalin, kadar protein menurun menjadi 3,80\%. Penurunan kadar protein tersebut dikarenakan adanya kerusakan protein oleh senyawa formaldehida. Kereaktifan formalin dapat menyebabkan terbentuknya ikatan silang dengan protein dimana formaldehid bereaksi dengan gugus amino $\mathrm{N}$-terminal dan rantai samping sistein, histidin, lisin, triptofan, dan arginin (Hoffman, et al., 2015) menyebabkan terbentuknya senyawa methylene $\left(-\mathrm{CH}_{2}-\right)$.

Setelah dilakukan perendaman terhadap tahu berformalin dengan berbagai konsentrasi sari lidah buaya dan sari lemon, diketahui bahwa terjadi peningkatan kadar protein pada tahu tersebut. Peningkatan tertinggi diperoleh pada perlakuan A1 (100\%:0\%) dimana kadar protein tahu sebesar 5,541\% dan peningkatan terendah pada perlakuan A6 (0\%:100\%) dimana kadar protein tahu sebesar 4,337\%.

Hal tersebut disebabkan karena adanya penurunan kadar formalin pada tahu setelah direndam pada sari lidah buaya dan sari lemon. Penurunan kadar formalin menyebabkan terputusnya ikatan silang antara protein dan formaldehid yang membentuk methylene, sehingga struktur protein kembali pada kondisi semula dan kadar protein tahu menjadi meningkat. Senyawa methylene dapat terurai kembali melalui reaksi hidrolisis membentuk protein dan formalin (Purawisastra dan Sahara, 2011). Adapun reaksi formalin dan protein dapat dilihat pada Gambar 1. 


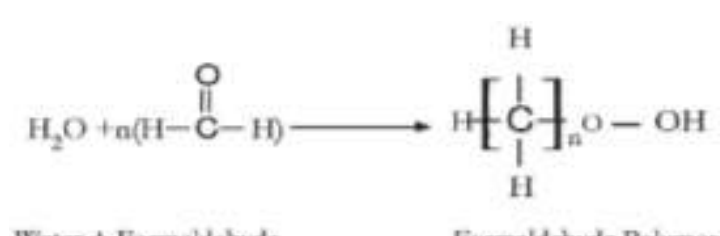

Water + Fomaldchyde

Formaldchyde Polymer

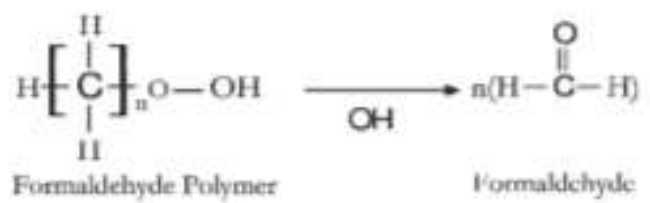

Gambar 1. Reaksi formalin dengan protein (Thavarajah, et al., 2012).

\section{Total Mikroba Selama \\ Penyimpanan}

Perlakuan yang terbaik adalah perlakuan yang mampu menurunkan kadar formalin terbesar, yaitu A1 (sari lidah buaya 100\%). Pengaruh lama penyimpanan terhadap total mikroba tahu dapat dilihat pada Tabel 3 .

Pada penyimpanan 3 hari, diketahui bahwa pada tahu yang diberi perlakuan formalin dijumpai pertumbuhan mikroba. Pada penyimpanan selanjutnya, jumlah mikroba semakin bertambah. Hal ini dikarenakan selama penyimpanan, formalin mengalami degradasi sehingga kandungan formalin menjadi menurun. Rendahnya kandungan formalin memungkinkan mikroba untuk tumbuh dalam tahu meskipun masih mengandung formalin. Bakteri anaerobik umumnya kurang rentan terhadap formalin karena dinding selnya yang kompleks, dimana membran bagian luarnya bertindak sebagai penghalang permeabilitas dalam membatasi atau mencegah masuknya banyak bahan kimia.

\section{KESIMPULAN}

Dalam penelitian ini keefektifan dari sari lidah buaya dengan sari lemon dilakukan dengan cara perbandingan konsentrasi. Berdasarkan hasil penelitian diperoleh sari lidah buaya $100 \%$ mampu menurunkan kadar formalin sebesar $57,05 \%$ dengan kadar formalin asal $84,214 \mathrm{mg} / \mathrm{kg}$ menjadi $36,163 \mathrm{mg} / \mathrm{kg}$, kehilangan kadar protein terendah jika dibandingkan terhadap kadar protein kontrol sebesar 6,331\% setelah perendaman sari lidah buaya $100 \%$ maka kadar protein yang dihasilkan sebesar $5,541 \%$ sehingga penurunan kadar protein hanya sekitar $12,48 \%$, hal ini bersifat linear terhadap jumlah mikroba yang tumbuh semakin lama perendaman tahu dengan sari lidah buaya $100 \%$ maka total mikrobanya semakin meningkat hal ini berkaitan dengan banyaknya jumlah formalin yang terurai oleh senyawa yang terkandung dalam lidah buaya sehingga ikatan silang antara protein dan fomaldehid terlepas. Penelitian ini perlu ditindaklanjuti dengan meningkatkan lama perendaman, perlu juga ditindaklanjuti pengaruhnya terhadap organ tubuh dengan menggunakan hewan percobaan yang akan dibandingkan dengan tahu yang mengandung formalin dan tahu tanpa formalin.

\section{DAFTAR RUJUKAN}

Ali, A. M., Devi, L. I., Nayan, V., Chanu, K. H. V. and Ralte, L. 2010. Antioxidant Activity of Fruits Available In Aizawl Market of Mizoram, India. International Journal of Biological and Pharmaceutical, 1(2):76-81. 
Badan Pengawas Obat dan Makanan (BPOM). 2017. Siaran Pers Gerakan Masyarakat Hidup Sehat Sadar Pangan Aman Kerja Bersama Menuju Indonesia Pangan Aman. http://www.pom.go.id. Diakses 23 November 2017.

Damayanti, E., W.F. Ma'ruf, dan I. Wijayanti. 2014. Efektivitas Kunyit (Curcuma lunga Linn) sebagai Pereduksi Formalin pada Udang Putih (Penaeus merguensis) Penyimpanan suhu dingin. Jurnal

Pengolahan dan Bioteknologi

Hasil Perikanan. 3(1):98 - 107

Gusviputri, A., Meliana, N. P. S., Aylianawati, and Indraswati, S. 2013. Pembuatan Sabun dengan Lidah Buaya (Aloe vera) sebagai Antiseptik

Alami, Widya Teknik, 12(1):11-21.

Hershey, A. D., and Chase, M. 2017. Independent Functions of Viral Protein And Nucleic Acid in Growth of Bacteriophage. Bayern Munchen: Springer.

Hoffman, E. A., Frey, B. L., Smith, L. M., and Auble, D. T. 2015.

Formaldehyde Crosslinking: A Tool For The Study of Chromatin Complexes. Journal Biology

Chemical. 290(44):2640426411.

Jannah, M., Ma'ruf, W. F., and Surti, T. 2014. Galangal Health as Reducing Formalin Levels in White Shrimp During Cold Storage. J. processing and Biotech. Fishery Products, (3)1:70-79.
Jooyandeh, H. 2011. Soy Products as Healthy and Functional Foods. Journal of Scientific Research, 7(1):71-80.

Purawisastra, S dan Sahara, E. 2011. Penyerapan Formalin oleh Beberapa Jenis Bahan Makanan Serta

Penghilangannya Melalui Perendaman dalam Air Panas. Jurnal Penelitian Gizi dan Makanan. 34(1).

Ramesh, G. A., Katiyar, R., Sujatha, A., Raj, B., Gupta, and Kumar., A., 2017. Detection of Microorganisms on

Formalin-Fixed and Stored Pathology Tissues: A

Microbiology Study Journal of Oral and Maxillofacial

Pathology. 21(1):64

Rosida, J. 2002. Uji Saponin dalam Lidah Buaya, Limbah Buah Mengkudu dan Daun Mimba. Makalah Laboratorium Penelitian. Temu Teknis Fungsional Non Peneliti. Balai Ternak Ciawi. Bogor. 75.

Shita, A. E., 2016. Selektivitas Metode Analisis Formalin Secara Spektrofotometri Dengan Pereaksi Schiff's.

Skripsi. Yogyakarta:

Universitas Negeri Yogyakarta. Thavarajah, R., Mudimbaimannar, V. K., Elizabeth, J., Rao, U. K., and Ranganathan, K., 2012. Chemical and Physical Basics of Routine Formaldehyde Fixation. Journal of Oral and Maxillofacial Pathology. 16(3): 400-405. 
CONNIE D., HERLA R., \& HOTNIDA S., EFEKTIVITAS...

Wikanta, W, 2011, Pengaruh

Penambahan Belimbing

wuluh dan Perebusan terhadap

Residu Formalin dan Profil

Protein Udang Putih

Berformalin serta

Pemanfaatanya sebagai Sumber

Pendidikan Gizi dan

Keamanan Pangan pada

Masyarakat, Pascasarjana FK

Ub, Surabaya.

Wirawan, Tantalu, L., and

Suliana, G., 2017.

Efektivitas Daun Singkong

(Manihot esculenta) Var.

Malang 1 sebagai

Pereduksi Kadar Formalin

pada Udang Putih (Pennaeus

vannamei). Jurnal Penelitian

Pertanian terapan. 17(3):170-

175. 